\title{
Prognostic Value of The Efficiency of Preoperative Neutrophil-to-Lymphocyte Ratio in Acute Mesenteric Ischemia Prognosis
}

\section{Akut Mezenter İskeminin Prognozunun Belirlenmesinde Preoperatif Nötrofil Lenfosit Oranının Etkinliği}

Kemal Deniz Ercan ${ }^{1}$,

Mehmet Aykut Yildirim ${ }^{1}$,

Mustafa Sentürk ${ }^{1}$,

Metin Belviranlı ${ }^{1}$,

Faruk Aksoy ${ }^{1}$

Necmettin Erbakan University Meram Medical Faculty, Department of General Surgery, Konya, Turkey

Geliş Tarihi/Received: 22 October 2018 Kabul Tarihi/Accepted: 15 December 2018

Address correspondence to: Mehmet Aykut Yildirim, Necmettin Erbakan University, Meram Medical Faculty, Department of General Surgery, Konya, Turkey

e-mail: drmayildirim@hotmail.com

ORCID

Kemal Deniz Ercan

https://orcid.org/0000-0001-9580-6004

\begin{abstract}
$\ddot{O} z$
Amaç: Akut mezenter iskemi (AMi) yaşa bağlı olarak artış gösteren ve kötü prognozu olabilen, erken tanı ve tedavide morbidite ve mortalite oranları \%10 iken, tanıve tedavide gecikmelerde \%100' e kadar mortal seyreden bir akut karın hastalığıdır. Bu çalışmada amacımız AMI'nin prognozunu göstermede son zamanlarda kullanılmaya başlanan ve birçok hastalıkta prognostik faktör olarak kullanılan NötrofilLenfosit Oranının (NLO) etkinliğini ortaya koymaktır.

Hastalar ve Yöntem: Bu çalışmada 2005 - 2013 yılları arasında Necmettin Erbakan Üniversitesi Meram Tıp Fakültesi Genel Cerrahi Kliniğinde opere edilen ve intraoperatif olarak mezenter iskemi tanısı konulan, sonrasında patolojik olarak tanısı doğrulanan 111 hastanın verileri retrospektif olarak değerlendirildi. Preoperatif değerlendirilmesinde periferik kandan çalışılan hemogram sonuçları tarandı. Hastalara uygulanan cerrahi işlem, patoloji raporuna göre çıkarılan barsağın bölümü ve uzunluğu, hastanede yatış süreleri, sağ kalım oranları, ek hastalığın varlığı, beyaz küre sayısı, kreatinin ve NLO değerleri belirlendi. Bulgular: Hayatını kaybeden hastalarda NLO ortalaması $24.77 \pm 10.38$, yaşayanlarda $17,6 \pm 10.65$ olarak bulundu.

Sonuç: Sonuç olarak AMI gelişen görüntüleme yöntemlerine ve laboratuvar tetkiklerine rağmen halen yüksek mortaliteye sahiptir. Erken tanı için spesifik bir laboratuvar testi yoktur. AMi şüphelenilen hastalarda preoperatif NLO'nın yüksek olması prognozun kötü olacağını gösterebilir.
\end{abstract}

Anahtar Kelimeler: Akut mezenter iskemi, nötrofil, lenfosit, oran

\begin{abstract}
Aim: Acute mesenteric ischemia (AMI) is an acute abdominal disease which is age-related with possible bad prognosis; and while its morbidity and mortality rate is $10 \%$ in early diagnosis and treatment it may progress with $100 \%$ mortality when diagnosis and treatment are delayed. The aim of this study was to unearth the efficiency of neutrophil-to-lymphocyte ratio (NLR) which has recently been started to be utilized in the prediction of AMI prognosis and used as a prognostic factor in many diseases.

Patients and Methods: The data of a total of 111 patients, who had undergone surgical procedures and diagnosed with mesenteric ischemia intraoperatively at Necmettin Erbakan University Meram Medical School's General Surgery Clinic between 2005 and 2013 and whose diagnoses had later on been confirmed pathologically, were retrospectively evaluated within the scope of the study.

The demographic data of all patients (age, sex) were recorded. The hemogram results of the patients, analyzed with peripheral blood, were reviewed for preoperative evaluation. The surgical procedure performed, the part and length of the resected bowel based on pathology results, the duration of hospitalization, survey, presence of comorbidity, white blood cell count, creatinine values, and NLR of the patients were determined. The data were statistically analyzed.

Results: The patients who did not survive had a mean NLR of $24.77 \pm 10.38$, while the same ratio was found to be $17.6 \pm 10.65$ for survivors. The NLO value was found to be high in cases with mortality. Conclusion: AMI still proves to have high mortality in spite of the developments in imaging techniques and laboratory analyses. There is no specific laboratory analysis for early diagnosis. High preoperative NLR in patients suspected to have AMI may indicate bad prognosis
\end{abstract}

Key words: Acute mesenteric ischemia, neutrophil, lymphocyte, ratio

\section{INTRODUCTION}

Acute mesenteric ischemia (AMI) is an acute abdominal disease which is age-related with possible bad prognosis; and while its morbidity and mortality rate is $10 \%$ in early diagnosis and treatment it may progress with $100 \%$ mortality when diagnosis and treatment are delayed (1). It still remains as a difficult to diagnose disease in current diagnostic and therapeutic modalities.

The neutrophil-to-lymphocyte ratio has recently drawn attention as an independent predictor in a wide spectrum of patients ranging from oncology to cardiovascular system patients $(2,3)$. The aim of this study was to unearth the efficiency of neutrophilto-lymphocyte ratio (NLR) which has recently been started to be utilized in the prediction of AMI prognosis
Cite this article as: Ercan KD, Yildirim MA, Senturk M, Belviranlı M, Aksoy F. Prognostic Value of The Efficiency of Preoperative Neutrophil-to-Lymphocyte Ratio in Acute Mesenteric Ischemia Prognosis. Selcuk Med J 2019;35(4): 230-234
Disclosure: None of the authors has a financial interest in any of the products, devices, or drugs mentioned in this article. The research was not sponsored by an outside organization. All authors have agreed to allow full access to the primary data and to allow the journal to review the data if requested. 
and used as a prognostic factor in many diseases.

\section{PATIENTS AND METHOD}

The data of a total of 111 patients, who had undergone surgical procedures and diagnosed with mesenteric ischemia intraoperatively at Necmettin Erbakan University Meram Medical School's General Surgery Clinic between 2005 and 2013 and whose diagnoses had later on been confirmed pathologically, were retrospectively evaluated within the scope of the study. Ethics committee approval was received for this study from the ethics committee of Necmettin Erbakan University(13.02.2015-2015/119). The demographic data of all patients (age, sex) were recorded. The hemogram results of the patients, analyzed with peripheral blood, were reviewed for preoperative evaluation. The surgical procedure performed, the part and length of the resected bowel based on pathology results, the duration of hospitalization, survey, presence of comorbidity, white blood cell count, creatinine values, and NLR of the patients were determined (Table 1).

The patients' latest preoperative hemogram results were investigated in order to calculate NLR values. NLR was calculated by dividing the neutrophil count by the lymphocyte count. The patients were classified as survivor and exitus, $<15$ and $\geq 15$ according to NLR value, $<65$ and $\geq 65$ according to age group, and $<1.5$ $\mathrm{mg} / \mathrm{dL}$ and $\geq 1.5 \mathrm{mg} / \mathrm{dL}$ according to creatinine values. Statistical analyses were conducted in order to reveal the relationships among NLR, white blood cell (WBC), creatinine values, mortality, and the length of

Table 1. The demographic data of and evaluation parameters for the patients.

\begin{tabular}{|c|c|c|c|}
\hline & & $\mathbf{n}$ & $\%$ \\
\hline \multirow[t]{2}{*}{$\overline{S e x}$} & $M$ & 49 & 44 \\
\hline & $\mathrm{F}$ & 62 & 56 \\
\hline \multirow{2}{*}{ Age } & $>65$ & 68 & 61.2 \\
\hline & $<65$ & 43 & 38.8 \\
\hline \multirow[t]{2}{*}{ AF } & + & 65 & 58.6 \\
\hline & - & 46 & 41.4 \\
\hline \multirow[t]{2}{*}{ NLR } & $>15$ & 78 & 70.3 \\
\hline & $<15$ & 33 & 29.7 \\
\hline \multirow[t]{2}{*}{ Creatinine } & $>1.5$ & 49 & 44.1 \\
\hline & $<1.5$ & 62 & 55.6 \\
\hline \multirow[t]{2}{*}{ Resection } & SB & 74 & 66.7 \\
\hline & SB+Colon & 37 & 32.4 \\
\hline \multirow[t]{2}{*}{ Relaparotomy } & + & 13 & 11.7 \\
\hline & - & 98 & 88.3 \\
\hline Survival & Ex & 53 & 47.7 \\
\hline Survivor & & 58 & 52.3 \\
\hline
\end{tabular}

SB: Small bowel; NLR: Neutrophil-to-Lymphocyte Ratio;AF:Atrial fibrillation; Ex:Exitus resected bowel. The Statistical Package for the Social Sciences20.0 (SPSS Inc.; Chicago, IL, USA)software was used for all the analyses conducted in the study. The data were statistically analyzed. $p<0.05$ was set as statistically significant in all analyses. The research was performed according to the World Medical Association Declaration of Helsinki.

\section{RESULTS}

The study covered a total of 111 patients who had undergone surgery having been diagnosed with $\mathrm{AMI}$ and whose diagnoses were histopathologically confirmed. While $62(56 \%)$ of these patients were male, $49(44 \%)$ were female. The mean age of the patients was $65.77 \pm 13.31$. Atrial fibrillation was seen in $65(58.6 \%)$ patients. While $74(66.7 \%)$ patients only had small bowel resection, it was observed that 36 $(32.4 \%)$ patients had either right/left hemicolectomy, subtotal colectomy, or partial colon resection in addition to small bowel resection. It was also observed that $58(52.3 \%)$ patients recovered in the postoperative period, while $53(47.7 \%)$ patients had postoperative early mortality. While the conditions of $13(11.7 \%)$ patients necessitated relaparotomy, $98(88.3 \%)$ patients did not need this procedure with regards to both complications and second-look laparotomy. The mean duration of hospitalization of the patients was found to be $8.28 \pm 7.58$ days.

When the cases of all patients were evaluated it was seen that the mean white blood cell value (WBC) was $17.200 \pm 7600 / \mathrm{mm}^{3}$, the mean NLR was $21.02 \pm 11.07$, the mean creatinine value was $1.86 \pm 1.23$, and the mean length of resected bowel segment was $168.2 \pm 109.02 \mathrm{~cm}$. The patients who did not survive had a mean NLR of $24.77 \pm 10.38$, while the same ratio was found to be $17.6 \pm 10.65$ for survivors. It was seen that $43(38.7 \%)$ patients were younger than 65 years, $68(61.3 \%)$ patients were older than 65 . There were $33(29.7 \%)$ patients in the group with an NLR value lower than 15, while there were $78(70.3 \%)$ patients in the group with an NLR value higher than 15. As the creatinine value is a parameter demonstrating the severity of the disease and organ damage, it was taken into careful consideration and it was seen that $62(55.9 \%)$ patients had a creatinine value lower than $1.49 \mathrm{mg} / \mathrm{dL}$ while $49(41.4 \%)$ patients had higher than $1.5 \mathrm{mg} / \mathrm{dL}$. The results of the statistical intergroup comparison revealed that WBC count was significantly lower in the 65 and older age group in comparison to that of the group with patients younger than 65 years $(p=0.047)$, while NLR was found to be 
Table 2. Statistical data on WBC, NLR, creatinine, and mortality according to age groups.

\begin{tabular}{llll}
\hline & $<65$ & $>65$ & $\mathbf{p}$ \\
\hline White blood cell count & $17900 \pm 8600$ & $16444 \pm 6900$ & 0.047 \\
NLR & $17.88 \pm 9.7$ & $23.01 \pm 11.48$ & 0.008 \\
Creatinine & $1.42 \pm 0.75$ & $2.13 \pm 1.39$ & 0.049 \\
Mortality & $11 \quad 42$ & 0.001 & \\
\hline
\end{tabular}

significantly higher in the 65 and older age group than the other group $(p=0.008)$ (Table 2).

Statistical analysis showed that the creatinine value was significantly higher in the 65 and older age group than the group with patients younger than 65 years $(p=0.049)$ (Table 2$)$. While the mortality rate was $61.8 \%$ (42 patients) in the 65 and $65+$ age group, it was $25.6 \%$ (11 patients) in the 65 - group (Table 2 ). The creatinine values for the patient group with an NLR of lower than 15 were lower than those of the patients in the group with an NLR value of 15 and higher $(p=0.042)$ (Table 3$)$. When mortality and NLR values were compared, it was observed that mortality was seen in $8(24.2 \%)$ patients in the group with an NLR value of lower than 15 , while it was seen 45 $(57.7 \%)$ patients in the group with an NLR value of 15 and higher.The mortality rate of the group with higher NLR was statistically significant $(p=0.001)$ (Table 3 ).

The results of the correlation analysis revealed that there was a positive correlation between WBC and NLR ( $p=0.002)$. While there was no correlation between WBC and creatinine values, a positive correlation between NLR and creatinine values was seen $(p=0.042)$ (Table 3$)$. There was no statistical significance between NLR and the length of the resected bowel segment $(p=0.987)$. Similarly, there was no statistical relationship among the length of the resected bowel segment and WBC, and creatinine values $(p=0.804, p=0.916$ respectively) (Table 4$)$.

\section{DISCUSSION}

Early diagnosis of AMI is hard and its mortality rate is high. There is neither any specific laboratory finding nor a specific imaging method. The incidence and mortality rates go up as it is an age-related syndrome. Comorbidities have an immense effect among the reasons why it has high mortality and morbidity rates and delay diagnosis (4, 5, 11-14). In our study, too, $61.3 \%$ of the patients were older than 65 years. $65(58.6 \%)$ of our patients had atrial fibrillation. While $58(52.3 \%)$ of our patients recovered in the postoperative period, postoperative early mortality was observed in $53(47.7 \%)$ patients. While mortality rates remain at $10 \%$ through immediate diagnosis and rapid intervention, delays in diagnosis and treatment may increase mortality to $100 \%$ (1). The fact that laparotomy showed gangrene in our cases stood testimony to delayed intervention. The reason for this was observed to have been based on the durations of analysis and referral beginning with the initial presenting hospitals of the patients.

There is an ample number of studies in current literature which show that NLR points to bad prognosis. NLR is an easily-obtained value in determining systemic inflammation and prognosis $(6-8,15,16)$. Increases in WBC may not be seen in elderly patients because of age-related anergia but increases in NLR, which is an indicator of systemic inflammation, are seen. Leukocytosis is the nonspecific marker of inflammation and infection. We, however, ascertained that there was an increase in NLR in our AMI patients rather than an increase in WBC in our study. We observed that the NLR value was significantly higher especially in patients older than 65 years rather than high white blood cell counts. As we were unable to find any information on the utilization of NLR in AMI in literature, we conducted comparisons related to its use in other diseases in order to demonstrate inflammatory process and prognosis. Indeed, Goodman et al. showed that NLR was more sensitive than WBC in the diagnosis of appendicitis (9). While there was a statistically significant relationship

Table 3. Statistical relationship among mortality, creatinine, and WBC according to NLR.

\begin{tabular}{llll}
\hline & NLR>15 & NLR<15 & P \\
\hline Mortality & $45(57.7 \%)$ & $8(24.2 \%)$ & 0.001 \\
Creatinine & $2.07 \pm 1.32$ & $1.35 \pm 0.79$ & 0.042 \\
White Blood Cell Count & $18000 \pm 7600$ & $14500 \pm 7000$ & 0.002 \\
\hline
\end{tabular}


Table 4. Statistical relationship between the resected bowel segment and NLR, WBC, and creatinine values.

\begin{tabular}{llll}
\hline & SB & SB + Colon & P \\
\hline NLR & $20.29 \pm 10.88$ & $22.49 \pm 11.45$ & 0.987 \\
White Blood Cell Count & $17000 \pm 7700$ & $16800 \pm 7000$ & 0.804 \\
Creatinine & $1.87 \pm 1.19$ & $183 \pm 1.32$ & 0.916 \\
\hline
\end{tabular}

between age and NLR and mortality in our study, no significant relationship was found among WBC count and these parameters.

An increase in the creatinine value can be regarded to be a sign of organ damage in AMI (11-14). The results of our study also revealed that the creatinine value in 65-year-old and older patients was higher than that of those younger than 65 years. Our results demonstrated that the creatinine values in the patient group with NLR values lower than 15 were lower than the group with NLR values higher than 15 as well $(p=0.042)$. The results of the correlation analyses pointed that there was no correlation between WBC and the creatinine values, while there was a positive correlation between NLR and creatinine values. Walsh et al. reported that high preoperative NLR was a bad prognostic factor for patients with colorectal cancer (10). Moreover, NLR was identified to be a marker for bad prognosis in breast, ovarian, gastric, and renal cancers and malign mesothelioma. We ascertained that mortality rates went up in patients with high NLR $(\geq 15)$. We, therefore, can state that prognosis will be bad in patients with high NLR. No correlation was found between the NLR value and the length of resected bowel segments within the scope of our study. Consequently, AMI still proves to have high mortality in spite of the developments in imaging techniques and laboratory analyses. There is no specific laboratory analysis for early diagnosis. High preoperative NLR in patients suspected to have AMI may indicate bad prognosis. NLR, which is one of the markers of systemic inflammatory response, can be a preoperative prognostic criterion in AMI as it is in many other diseases. We ascertained that high NLR was related to bad prognosis in AMI. This conclusion demonstrates that NLR calculation within full blood count, which is routinely analyzed in all preoperative patients, can be utilized as an independent marker in the prediction of prognosis.

Ethics Committee Approval: Ethics committee approval was received for this study from the ethics committee of Necmettin Erbakan University(13.02.2015-2015/119). Authors declared that there search was conducted according to the principles of the World Medical Association Declaration of Helsinki "Ethical Principles for Medical Research Involving Human Subjects", (amended in October 2013).

Conflict of interest: Authors declare that there is no conflict of interest between the authors of the article.

Financial conflict of interest: Authors declare that they did not receive any financial support in this study.

Address correspondence to: Mehmet Aykut Yildirim Necmettin Erbakan University, Meram Medical Faculty, Department of General Surgery, Konya, Turkey

Postal Code: 42080 Telephone: +90 3322236148

e-mail:drmayildirim@hotmail.com

\section{REFERENCES}

1. Paes E, Vollmar JF, Hutschenreiter S, et al. Diagnostik und therapie des akuten mesenterial infarktes. Chir Gastroenterol 1990;6:473-80.

2. Ommen SR, Hodge DO, Rodeheffer RJ, et al. Predictive power of the relative lymphocyte concentration in patients with advanced heart failure. Circulation 1998; 97:19-22.

3. Sarraf KM, Belcher E, Raevsky E, et al. Neutrophil/ lymphocyte ratio and its association with survival after complete resection in non-small cell lung cancer. J Thorac Cardiovasc Surg 2009;137:425-8.

4. Stoney RJ, Cunningham CG. Acute mesenteric ischemia. Surgery 1993;114:489-90.

5. Acosta S. Epidemiology of mesenteric vascular disease: Clinical implications. Semin VascSurg 2010;23:4-8.

6. Yamanaka T, Matsumoto S, Teramukai S, et al. The baseline ratio of neutrophils to lymphocytes is associated with patient prognosis in advanced gastric cancer. Oncology 2007;73:215-20.

7. Cho H, Hur HW, Kim SW, et al. Pre-treatment neutrophil to lymphocyte ratio is elevated in epithelial ovarian cancer and predicts survival after treatment. Cancer Immunol Immunother 2009;58:15-23.

8. Perez DR, Baser RE, Cavnar MJ, et al. Blood neutrophilto- lymphocyte ratio is prognostic in gastrointestinal stromal tumor. Ann Surg Oncol 2013;20:593-9.

9. Goodman DA, Goodman CB, Monk JS. Use of the neutrophillymphocyte ratio in the diagnosis of appendicitis. Am Surg 1995;61:257-9.

10. Walsh SR, Cook EJ, Goulder F, et al. Neutrophil-lymphocyte ratio as a prognostic factor in colorectal cancer. J SurgOncol 2005;91:181-4

11. Yıldırım D, Hut A, Tatar C, et al. Prognostic factors in patients with acute mesenteric ischemia. Turk J Surg 2017 1;33(2):104-9. 
12. Aliosmanoglu I, Gul M, Kapan M, et al. Risk factors effecting mortality in acute mesenteric ischemia and mortality rates: A single center experience. Int Surg 2013;98:76-81.

13. Lawson RM. Mesenteric ischemia. Crit Care Nurs Clin North Am 2018;30(1):29-39.

14. Wang Z, Chen JQ, Liu JL, et al. A novel scoring system for diagnosing acute mesenteric ischemia in the emergency ward. World J Surg 2017;41(8):1966-74.
15. Ozer I, Balevi S, Ataseven A. Can Neutrophil/lymphocyte ratio be used as a marker in the diagnosis of bullous pemphigoid? Selcuk Med J 2018;34(2):65-9.

16. Yıldırım MA, Kartal $A$, Şentürk $M$, et al. Do neutrophil/ lymphocyte and platelet ratios determine surgical treatment method in peptic ulcer? Selcuk Med J 2016;32(3):56-7. 